\title{
Gambaran Pengetahuan Mahasiswa Universitas Sahid Surakarta tentang Obat Generik
}

\author{
Overview of Knowledge of Students of Universitas Sahid Surakarta about Generic Medicine \\ Riska Dwi Astuti( $^{(1)}$, Khotimatul Khusna ${ }^{(2)}$, Risma Sakti Pambudi(3) \\ (1) (2) (3)Farmasi , Universitas Sahid Surakarta \\ Email : khotimatul.usahid@gmail.com
}

\begin{abstract}
ABSTRAK
Obat generik merupakan obat paten yang telah habis masa patennya sehingga di produksi semua perusahaan farmasi tanpa harus membayar royalti. Obat generik terbagi menjadi 2 (dua) jenis, yaitu obat generik bermerek dagang dan obat generik berlogo. Permasalahan yang terjadi pada masyarakat selama ini adalah mereka menganggap bahwa obat generik adalah obat yang murah dan tidak berkualitas. Hal itu di sebabkan oleh kurangnya edukasi dan sosialisai dasar lebih lanjut terhadap obat generik. Mahasiswa dinilai memiliki tingkat intelektualitas yang tinggi, kecerdasan dalam berfikir dan kerencanaan dalam bertindak. Tujuan penelitian ini adalah untuk mengetahui gambaran tingkat pengetahuan obat generik pada mahasiswa Universitas Sahid Surakarta. Penelitian ini termasuk jenis penelitian observasional deskriptif dengan rancangan crosssectional. Variabel penelitian ini adalah tingkat pengetahuan obat generik. Responden penelitian ini mahasiswa yang terdaftar sebagai angkatan 2017. Teknik pengambilan sampel menggunakan non random sampling. Instrumen yang digunakan berupa kuesioner. Analisa data dilakukan secara deskriptif dengan menampilkan peresentase tingkat pengetahuan $76-100 \%$ tingkat pengetahuan tinggi, 56-75\% tingkat pengetahuan sedang dan 0-56\% tingkat pengetahuan rendah. Hasil penelitian ini menunjukan tingkat pengetahuan obat generik pada mahasiswa Universitas Sahid Surakarta adalah tingkat pengetahuan tinggi sebanyak 36 responden $(51,43 \%)$, tingkat pengetahuan sedang sebanyak 19 responden $(27,14 \%)$, dan tingkat pengetahuan rendah sebanyak 15 responden $(21,43 \%)$.
\end{abstract}

Kata kunci: obat, generik, mahasiswa, pengetahuan

ABSTRACT

Generic drugs are patent drugs whose patents have expired so that all pharmaceutical companies produce them without having to pay royalties. Generic drugs are divided into 2 (two) types: trademarked generic drugs and logo generic drugs. The community problems are that they think that generic drugs are cheap and have no quality. This is caused by lack of education and further basic socialization of generic drugs. Students are considered to have a high level of intelligence, intelligence in thinking and planning in action. The objective of this study was describe the level of knowledge of generic drugs among students at the University of Sahid Surakarta. This research variable is the knowledge level of generic drugs. The respondents of this study are students of 2017. The sampling technique used non-random sampling. The instrument used was a questionnaire. Data analysis was carried out descriptively by showing the percentage of knowledge level: 76-100\% high knowledge, 56-75\% medium knowledge level and $0-56 \%$ low knowledge level. The results indicate that the level of knowledge og generic drugs in students of the Sahid Surakarta University is a high level of knowledge with 19 respondents $(27,14 \%)$, and a low level of knowledge with 15 respondents $(21,43 \%)$.

Keywords: drug, generic, students, knowledge 


\section{PENDAHULUAN}

Obat generik merupakan obat paten yang telah habis masa patennya sehingga di produksi semua perusahaan farmasi tanpa harus membayar royalti. Obat generik terbagi menjadi 2 (dua) jenis, yaitu obat generik bermerek dagang dan obat generik berlogo. Obat generik berlogo adalah obat yang dipasarkan dengan merek kandungan zat aktifnya. Sedangkan obat generik bermerek adalah kandungan zat aktif itu diberi nama (merek). Zat aktif atau komponen utama obat, antara obat generik berlogo maupun bermerek dagang, sama persis dengan obat paten. Sedangkan obat generik lebih murah dibanding obat yang paten. Mutu obat generik tidak berbeda dengan obat paten karena bahan bakunya sama. Obat generik kemasannya dibuat biasa, karena yang terpenting bisa melindungi produk yang ada di dalamnya. Sedangkan, yang bermerek dagang kemasannya dibuat lebih menarik dengan berbagai warna. Kemasan itulah yang membuat obat bermerek lebih mahal(Kementerian Kesehatan Republik Indonesia, 2012).

Pengetahuan merupakan segala sesuatu yang diketahui berdasarkan pengalaman pengalaman manusia itu sendiri dan pengetahuan akan bertambah sesuai dengan proses pengalaman yang dialaminya(Mubarak, 2011). (Kementrian Kesehatan Republik Indonesia, 2013) menunjukkan pengetahuan masyarakat tentang obat generik, dalam skala nasional menunjukkan 31,9\% masyarakat yang mengetahui atau pernah mendengar tentang obat generik, sejumlah $85,9 \%$ tidak memiliki pengetahuan yang benar tentang obat generik, sedangkan masyarakat Indonesia yang memiliki pengetahuan yang benar tentang obat generik sebesar 14,1\% (Kemenkes RI, 2013). Hal ini membutikan bahwa banyak masyarakat belum mempunyai pengetahuan yang benar tentang obat generik.
Mahasiswa sebagai individu yang sedang menuntut ilmu ditingkat tinggi, baik negeri maupun swasta atau lembaga lain yang setingkat dengan perguruan tinggi. Mahasiswa dinilai memiliki tingkat intelektualitas yang tinggi, kecerdasan dalam berfikir dan kerencanaan dalam bertindak. Berpikir kritis dan bertindak dengan cepat dan tepat merupakan sifat yang cenderung melekat pada diri setiap mahasiswa, yang merupakan prinsip yang saling melengkapi (Siswoyo, 2007). Mahasiswa farmasi merupakan calon tenaga kesehatan yang akan bertugas dan bertanggung jawab dalam memberikan informasi obat. Hasil penelitian sebelumnya (Siwi, 2020) menunjukan bahwa mahasiswa farmasi memiliki tingkat pengetahuan yang baik $77,99 \%$, sedangkan tingkat pengetahuan non farmasi berjumlah $31,58 \%$. Berdasarkan fenomena tersebut maka penulis tertarik untuk meneliti tentang pengetahuan obat generik. Tujuan dari penelitian ini adalah mengetahui gambaran tingkat pengetahuan obat generik pada mahasiswa Universitas Sahid Surakarta. Hasil dari penelitian ini di harapakan dapat menggambarkan tingkat pengetahuan obat generik pada mahasiswa Universitas Sahid Surakarta.

\section{METODE PENELITIAN}

\section{Alat dan Bahan}

Alat dan bahan yang digunakan pada penelitian ini antara lain handphone, laptop, dan kuesioner. Kuesioner dibagikan melalui link menggunakan aplikasi googleform.

\section{Metode Penelitian}

Penelitian ini merupakan penelitian deskriptif observasional dengan pendekatan cross sectional. Populasi dalam penelitian ini adalah seluruh mahasiswa Universitas Sahid Surakarta angkatan 2017. Sampel dalam penelitian ini adalah mahasiswa Universitas 
Sahid Surakarta angkatan 2017 yang meliputi kriteria inklusi dan eksklusi.

Kriteria inklusi pada penelitian ini adalah mahasiswa Universitas Sahid Surakarta angkatan 2017 dan bersedia mengisi kuesioner. Kriteria eksklusi adalah mahasiswa yang tidak aktif dan mengundurkan diri.

Pengambilan data dilakukan pada bulan Januari-Februari 2021. Pengumpulan data dilakukan dengan menyebarkan kuesioner yang dibuat dalam aplikasi googleform. Kuesioner terdiri dari lembar persetujuan sebagai responden dan pertanyaan terkait obat generik. Tersedia pilihan jawaban "Ya" dan "Tidak" dalam kuesioner bagian ini, dengan skor "Ya" = 1 dan "Tidak" $=0$ untuk setiap pertanyaan positif, sedangkan pertanyaan negatif skor "Ya"= 0 dan "Tidak" $=1$.

Proses pengolahan data terdapat langkah-langkah yang harus ditempuh, diantaranya :

a. Editing adalah upaya untuk memeriksa kembali lembar observasi yang telah diisi, pengecekan yang dilakukan meliputi kelengkapan, kejelasan, relevansi serta konsistensi jawaban responden.

b. Coding merupakan kegiatan pemberian kode numerik (angka) terhadap data yang terdiri atas beberapa kategori. Pemberian kode ini sangat penting bila pengolahan dan analisis data menggunakan komputer. Biasanya dalam pemberian kode dibuat juga daftar kode dan artinya dalam satu buku (code book) untuk memudahkan kembali melihat lokasi dan arti suatu kode dari suatu variabel.

c. Skoring adalah Pemberian skor atau nilai pada setiap jawaban yang diberikan oleh responden

d. Tabulasi dimaksudkan untuk memasukan data ke dalam tabel-tabel dan mengatur angka-angka sehingga dapat dihitung jumlah kasus dalam berbagai kategori.

e. Entry Data adalah kegiatan memasukkan data yang telah dikumpulkan ke dalam master tabel atau data base komputer, kemudian membuat distribusi frekuensi sederhana atau bisa dengan membuat tabel kontingensi.

f. Cleaning Data yaitu proses pengecekan kembali data-data yang telah dimasukkan untuk melihat ada tidaknya kesalahan, terutama kesesuaian pengkodean yang dilakukan.

Analisa data dilakukan dengan menghitung presentase data karakteristik responden, meliputi umur, jenis kelamin, dan program studi. Tingkat pengetahuan dianalisis dengan menghitung presentase mahasiswa yang termasuk tingkat pengetahuan tinggi (76\%$100 \%)$, tingkat pengetahuan sedang $(56 \%-75 \%)$, dan tingkat pengetahuan rendah $(0 \%-56 \%)$.

\section{HASIL DAN PEMBAHASAN}

Hasil

\section{Uji Validasi dan Reliabilitas}

Sebelum kuesioner digunakan untuk penelitian, dilakukan uji validasi dan realibilitas pada 60 responden. Uji dilakukan menggunakan aplikasi googleform. Hasil dari uji kuesioner didapatkan bahwa dari 15 pertanyaan yang sudah diberikan, ada 6 pertanyaan yang tidak valid dan 9 pertanyaan pada kuesioner yang valid. Pertanyaan yang valid adalah pertanyaan yang memiliki $r$ hitung $\geq r$ tabel. Pertanyaan yang valid kemudian dilakukan uji realibilitas. Hasil uji kuesioner dinyatakan reliable karena nilai cronbach's alpha yang didapatkan $\geq 0,60$ yaitu 0,614 .

\section{Karakteristik Responden}

Responden yang memenuhi kriteria inklusi dan eksklusi pada penelitian ini berjumlah 70 mahasiswa. Karakteristik responden pada penelitian ini meliputi usia, jenis kelamin, dan asal program studi. 
Tabel 1. Karakteristik Responden

\begin{tabular}{lcc}
\hline \multicolumn{1}{c}{ Karakteristik } & Jumlah & Persentase (\%) \\
\hline Usia & & \\
21 tahun & 26 & 37,1 \\
22 tahun & 20 & 28,6 \\
23 tahun & 11 & 15,7 \\
24 tahun & 6 & 8,6 \\
25 tahun & 7 & 10 \\
\hline Jenis kelamin & & \\
Laki-laki & 38 & 54,28 \\
Perempuan & 32 & 45.72 \\
\hline Program Studi & & \\
Farmasi & 13 & 18.6 \\
Ilmu Keprawatan & 5 & 7,2 \\
Psikologi & 4 & 5,8 \\
Desain Interior & 3 & 4,2 \\
Desian Komunikasi & 15 & 21,4 \\
Visual & & \\
Ilmu Administrasi & 6 & 8,6 \\
Bisnis & & \\
Ilmu Komunikasi & 9 & 12,8 \\
Teknik Industri & 3 & 4,2 \\
Teknik Informatika & 12 & 17,2 \\
\hline Total & 70 & $100 \%$ \\
\hline
\end{tabular}

Berdasarkan tabel 1 dapat dilihat bahwa mayoritas usia responden 21 tahun sebesar 26 $(37,1 \%)$. Karakteristik berdasarkan jenis

\section{Pembahasan}

Data karakteristik berdasarkan umur pada tabel 1 menunjukkan mahasiswa tingkat akhir rata-rata berusia 21 tahun sebanyak 26 responden $(37,1 \%)$, sedangkan yang memiliki rentang usia 25 tahun sebanyak 24 responden (10\%). Hasil penelitian ini sejalan dengan penelitian yang dilakukan oleh (Siwi, 2020) bahwa sebagian besar responden berusia 21 tahun $(50,49 \%)$ mahasiswa tingkat akhir.

Data karakteristik responden berdasarkan jenis kelamin menunjukkan sebagian besar responden laki-laki dengan jumlah responden 38 (54,28\%), sedangkan responden perempuan dengan jumlah 32 (45,72\%). Hasil dari jumlah 233 mahasiswa angkatan 2017 mahasiswa paling banyak adalah mahasiswa dari program studi desain komunikasi visual dengan kelamin mayoritas adalah responden laki-laki sebesar 38 (54,28\%). Mahasiswa yang paling banyak menjadi responden adalah mahasiswa program studi desain komunikasi visual sebesar $15(21,4 \%)$.

\section{Tingkat Pengetahuan}

Gambaran tingkat pengetahuan dapat dilihat pada tabel 3 .

Tabel 3. Tingkat Pengetahuan Penggunaan Obat Generik Pada Mahasiswa Universitas Sahid Surakarta

\begin{tabular}{ccc}
\hline Tingkat pengetahuan & Jumlah & Persentase (\%) \\
\hline Tinggi & 36 & 51,43 \\
Sedang & 19 & 27,14 \\
Rendah & 15 & 21,43 \\
\hline Total & 70 & $100 \%$ \\
\hline
\end{tabular}

Tabel 3 menunjukkan bahwa mahasiswa yang memiliki tingkat pengetahuan tinggi sebanyak 36 responden $(51,4 \%)$, tingkat pengetahuan sedang sebanyak 19 responden $(27,1 \%)$, dan tingkat pengetahuan rendah sebanyak 15 responden $(21,4 \%)$.

mayoritas mahasiswa terbanyak adalah laki-laki, sehingga berdasarkan penelitian tersebut dapat diketahui bahwa responden laki-laki lebih banyak.

Data karakteristik responden berdasarkan program studi menunjukkan sebagian besar responden desain komunikasi visual dengan jumlah 15 responden $(21,4 \%)$, sedangkan persentase terkecil responden desain interior dan teknik industri dengan jumlah 3 responden $(4,2 \%)$. Hal tersebut di sebabkan karena program studi responden lebih banyak menanggapi kuesioner yang telah diberikan. Menurut data Biro Administrasi Akademik dan Kemahasiswaan (BAAK) mahasiswa angkatan 2017 paling banyak adalah mahasiswa dalam program studi desain komunikasi visual. 
Penelitian ini menunjukkan tingkat pengetahuan obat generik responden memiliki tingkat pengetahuan tinggi sebanyak $51,43 \%$. Penelitian ini sejalan dengan penelitian (Morison et al., 2015) yang menyatakan bahwa pengetahun baik atau memadai dengan jumlah $53,5 \%$ responden. Hal ini terjadi karena pada umunya responden cukup memahami dan mengetahui tentang obat generik.

Responden yang memiliki tingkat pengetahuan tinggi dengan usia 21 tahun sebanyak 14 responden, usia 22 tahun sebanyak 8 responden, usia 23 sebanyak 8 responden, usia 24 tahun sebanyak 3 responden, dan usia 25 sebanyak 3 responden. Penelitian ini sejalan dengan penelitian yang dilakukan oleh (Rahmawati, 2016), yang menyatakan bahwa usia 18-25 tahun termasuk dewasa muda dimana pada usia tersebut responden mudah menyerap informasi dan pengetahuan yang diperoleh baik.

Responden berdasarkan jenis kelamin yang memiliki tingkat pengetahuan tinggi adalah jenis kelamin laki-laki dengan jumlah 20 responden, dan jenis kelamin perempuan memiliki jumlah terkecil yaitu 16 responden. Penelitian ini sejalan dengan penelitian yang dilakukan oleh (Rahmawati, 2016) yang menyatakan bahwa berdasarkan jenis kelamin laki-laki sebanyak $63,2 \%$ sedangkan perempuan $58.8 \%$. Jenis kelamin merupakan salah satu faktor yang dapat mempengaruhi individu dalam menyikapi suatu produk atau jasa pelayanan termasuk penentuan sikap dalam pemilihan obat (Mochtar, 2014).

Responden yang memiliki tingkat pengetahuan tinggi adalah program studi farmasi sebanyak 12 responden, program studi ilmu administrasi bisnis 3, program studi ilmu komunikasi memiliki jumlah 6 , program studi teknik informatika memiliki jumlah 6 responden, program studi keperawatan memiliki jumlah 5 responden, program studi desain komunikasi visual memiliki jumlah 1 responden, program studi teknik industri memiliki jumlah 2 responden, program studi psikologi memiliki jumlah 1 responden. Penelitian ini selajan dengan penelitian (Siwi, 2020) yang menunjukkan tingkat pengetahuan farmasi memiliki tingkat pengetahuan baik dengan jumlah $77,99 \%$, sedangkan tingkat pengetahuan non farmasi berjumlah 31,58\%. Tingkat pengetahuan farmasi tinggi disebabkan karena, mahasiswa farmasi sudah mendapatkan informasi atau materi tersebut dalam mata kuliah, maupun pengalaman pada saat sakit dan memperoleh informasi dari apotek atau fasilitas kesehatan lainnya yang pada saat pengambilan obat telah dijelaskan mengenai obat generik tersebut.

\section{SIMPULAN}

Kesimpulan pada penelitian ini adalah mahasiswa dengan tingkat pengetahuan tinggi sebanyak 36 responden $(51,43 \%)$, tingkat pengetahuan sedang sebanyak 19 responden $(27,14 \%)$, dan tingkat pengetahuan rendah sebanyak 15 responden $(21,43 \%)$.

\section{UCAPAN TERIMA KASIH}

Ucapan terimakasih disampaikan kepada seluruh civitas akademika Universitas Sahid Surakarta yang telah banyak membantu dalam penyelesaian penelitian ini. Penelitian ini dikerjakan menggunakan sumber dana mandiri.

\section{DAFTAR PUSTAKA}

Kementerian Kesehatan Republik Indonesia. (2012). Peraturan Mentri Kesehatan Indonesia Nomor HK.02.02/MENKES/068//2010 tentang Pedoman Pelaksanaan Jaminan Kesehatan Masyarakat. Kementerian Republik Indonesia, Jakarta.

Kementrian Kesehatan Republik Indonesia. (2013). Riset Kesehatan Dasar. Jakarta.

Mochtar, M. (2014). Pengaruh Tingkat Pengetahuan Dengan Persepsi Masyarakat Tentang Obat Generik di Kecamatan Magetan Kabupaten 
Magetan. Universitas Muhammadyah Surakarta.

Morison, F., Utari, E., \& Fajriaty. (2015). Analisis Tingkat Pengetahuan dan Presipsi Masyarakat Kota Sungkawang. Jurnal Farmasi Klinik, IV, 39-48.

Mubarak, W. (2011). Promosi Kesehatan. Graha Ilmu.

Rahmawati. (2016). Gambaran Tingkat Pengetahuan Masyarakat Tentang Obat Generik Di Desa Dirgahayu Kecamatan Pulau Laut Utara Kabupaten Kotabaru Kalimantan Selatan. Universitas Muhammadiyah Yogyakarta.

Siswoyo. (2007). Ilmu Pendidikan. UNY Press. Siwi. (2020). Tingkat Pengetahuan Penggunaan Obat Generik Pada Mahasiswa Farmasi dan Non Farmasi di Universitas Sanata Dharma. Universitas Sanata Dharma, Yogyakarta.

Kementerian Kesehatan Republik Indonesia. (2012). Peraturan Mentri Kesehatan Indonesia Nomor HK.02.02/MENKES/068//2010 tentang Pedoman Pelaksanaan Jaminan Kesehatan Masyarakat. Kementerian Republik Indonesia, Jakarta.
Kementrian Kesehatan Republik Indonesia. (2013). Riset Kesehatan Dasar. Jakarta.

Mochtar, M. (2014). Pengaruh Tingkat Pengetahuan Dengan Persepsi Masyarakat Tentang Obat Generik di Kecamatan Magetan Kabupaten Magetan. Universitas Muhammadyah Surakarta.

Morison, F., Utari, E., \& Fajriaty. (2015). Analisis Tingkat Pengetahuan dan Presipsi Masyarakat Kota Sungkawang. Jurnal Farmasi Klinik, IV, 39-48.

Mubarak, W. (2011). Promosi Kesehatan. Graha Ilmu.

Rahmawati. (2016). Gambaran Tingkat Pengetahuan Masyarakat Tentang Obat Generik Di Desa Dirgahayu Kecamatan Pulau Laut Utara Kabupaten Kotabaru Kalimantan Selatan. Universitas Muhammadiyah Yogyakarta.

Siswoyo. (2007). Ilmu Pendidikan. UNY Press.

Siwi. (2020). Tingkat Pengetahuan Penggunaan Obat Generik Pada Mahasiswa Farmasi dan Non Farmasi di Universitas Sanata Dharma. Universitas Sanata Dharma, Yogyakarta. 